\title{
Type and Neotype Strains of the Species of Phototrophic Bacteria Maintained in Pure Culture
}

\author{
NORBERT PFENNIG and HANS G. TRÜPER \\ Institut für Mikrobiologie der GSF, 34 Göttingen, Germany
}

\begin{abstract}
The type or neotype strains of 41 species of phototrophic bacteria are given. Thirteen types, of which four are designated as types by the authors, are cited. Twenty-eight neotype strains, twenty-four of which are designated as neotypes, are also given. Fifteen of the newly designated neotype strains are described and references are given to previously published descriptions of the other nine neotypes.
\end{abstract}

According to Rule 9 of the International Code of Nomenclature of Bacteria (7), a type should be designated for each named taxon. The type of a species is preferably a living strain maintained in a culture collection or, if neither type nor neotype strains exist, the type is the original description or illustration. Among the phototrophic bacteria only very few type strains were designated by the original authors. For example, most species of the Chromatiaceae and Chlorobiaceae were originally described from natural sources and crude cultures $(8,27)$ so that no pure cultures of type strains existed. During the past 10 years, however, many representative strains of described species of these families have been isolated in pure culture, and a number of new species were described.

In view of the increasing number of studies on phototrophic (photosynthetic) bacteria, it is necessary to facilitate the identification of new isolates by the designation of type and neotype strains of the already named species. For species of phototrophic bacteria presently available in pure culture, we will cite or designate the type or neotype strains (Tables $1-3$ ).

Table 1 represents species that were originally described from pure cultures. In most of these cases the original description contains the designation of a type strain. In a few cases, however, a type strain was not designated (viz. Ectothiorhodospira shaposhnikovii, Chloropseudomonas ethylica, Rhodomicrobium vannielli, and Rhodospirillum molischianum). Since strains on which the original descriptions of these four species were based are still available and have been deposited in type culture collections, we herewith designate the strains cited in Table 1 as the type strains for these species.

Table 2 lists those species for which the type had never been isolated or was lost, and for which the strains listed were proposed as neotypes, but not in all cases in accordance with Rule $9 d(1)$ Note 2(c) of the bacteriological code (7). In those cases where neotypes were not properly proposed, the strains are here designated as neotypes.

Table 3 lists species of phototrophic bacteria (available in pure cultures) for which types were never designated or were lost and for which neotypes have not been proposed to date. Therefore, we hereby designate the strains listed in Table 3 as neotype strains. In the cases of Rhodopseudomonas capsulata, R. gelatinosa, $R$. palustris, and $R$. rubrum, the descriptions of the neotype strains are in complete agreement with the species descriptions given by van Niel (25). These strains are indeed those on which van Niel based his species descriptions and which he deposited at the American Type Culture Collection. Therefore we omit here the repetition of those descriptions. The other designated neotype strains are, in our opinion, in sufficiently close agreement with the original descriptions of the organisms to make them suitable as neotypes.

Rhodospirillum photometricum, neotype strain NTHC132.

Cells spiral shaped, 1.2 to $1.5 \mu \mathrm{m}$ wide; one complete turn of spiral 4 to $6 \mu \mathrm{m}$ wide and 7 to $10 \mu \mathrm{m}$ long. Cells 14 to $30 \mu \mathrm{m}$ long not uncommon. Internal photosynthetic membrane system consisting of several stacks of short lamellae; the stacks are not parallel to the 
TABLE 1. Type strains of phototrophic bacteria

\begin{tabular}{|c|c|c|c|}
\hline Species & $\begin{array}{l}\text { Original strain } \\
\text { designation }\end{array}$ & $\begin{array}{c}\text { Culture } \\
\text { collection no. }{ }^{a}\end{array}$ & $\begin{array}{l}\text { Description of species } \\
\text { and type strain by }\end{array}$ \\
\hline Ectothiorhodospira halophila & SL1 $b$ & SMG 244 & Raymond and Sistrom (20) \\
\hline Ectothiorhodospira shaposhnikovii. & $1^{c}$ & KMMGU, N1; SMG 243 & Cherni et al. (1) \\
\hline Chlorobium phaeobacteroides .... & Blankvann; $2430^{b}$ & SMG 266 & Pfennig (14) \\
\hline Chlorobium phaeovibrioides & Langvik; $2631^{b}$ & SMG 269 & Pfennig (14) \\
\hline Chloropseudomonas ethylica & $1 \mathrm{M}^{c}$ & KMMGU, 1M & Shaposhnikov et al. (21) \\
\hline Chromatium buderi ....... & Sta. Cruz; $8111^{b}$ & ATCC 25588; SMG 176 & Trüper and Jannasch (24) \\
\hline Prosthecochloris aestuarii. & SK-413b & SMG 271 & Gorlenko (6) \\
\hline Rhodomicrobium vannielii & - & ATCC $17100^{c}, d$ & Duchow and Douglas $(3)^{b}$ \\
\hline Rhodopseudomonas acidophila & Crystal Lake; $7050^{b}$ & ATCC 25092; SMG 137 & Pfennig (15) \\
\hline Rhodopseudomonas viridis . . & Dreisam; F $b$ & ATCC 19567 & Drews and Giesbrecht (2) \\
\hline Rhodospirillum molischianum & $5 ; S^{c, e}$ & ATCC 14031 & Giesberger $(5)^{c}$ \\
\hline Rhodospirillum tenue .. & Grünenplan; $2761^{b}$ & ATCC 19137; SMG 109 & Pfennig (16) \\
\hline Thiocapsa pfennigii . . & Nidelven $^{b}$ & NTHC, Nidelven & Eimhjellen (4) \\
\hline
\end{tabular}

$a$ Abbreviations: SSMG, Sammlung fur Mikroorganismen Göttingen, Göttingen, Germany; ATCC, American Type Culture Collection, Rockville, Md.; NTHC, Norwegian Technical University Collection of Microorganisms, Trondheim, Norway; KMMGU, Collection of Microorganisms, of Moscow State University, Moscow, USSR.

$b$ Designated as the type strain by the original author.

$c$ Here designated as the type strain.

${ }^{d}$ C. B. van Niel reported (personal communication) that he received this strain, on which the original species description by Duchow and Douglas (3) was based, from these authors and deposited it with the ATCC.

$e$ C. B. van Niel (personal communication) confirmed the identity of Geisberger's strain 5 with strain ATCC 14031.

cytoplasmic membrane but form a sharp angle to it. Do not contain gas vacuoles. Cells motile by means of polar flagella. Anaerobic liquid cultures are orange brown to reddish brown.

Photosynthetic pigments: bacteriochlorophyll a.
Carotenoids: predominantly rhodopin and lycopene. Gram reaction: negative.

Photoorganotrophs, growing anaerobically in the light; unable to adapt to growth under aerobic conditions. In deep-agar tubes in the dark, microaerophilic growth occurs 5 to

TABLE 2. Strains previously suggested or designated as neotypes of phototrophic bacteria

\begin{tabular}{|c|c|c|c|}
\hline Species & $\begin{array}{c}\text { Original } \\
\text { designation }\end{array}$ & $\begin{array}{l}\text { Culture } \\
\text { collection no. } a\end{array}$ & $\begin{array}{c}\text { Neotype } \\
\text { described by }\end{array}$ \\
\hline Amoebobacter pendens. & Kleinkalden; $1314^{b}$ & SMG 236 & Pfennig and Trüper (17) \\
\hline Ectothiorhodospira mobilis & Sta. Cruz I; $8112^{c}$ & SMG 237 & Trüper (23) \\
\hline Lamprocystis roseopersicina & Bergkamen; $3012^{c}$ & SMG 229 & Pfennig et al. (19) \\
\hline Pelodictyon luteolum & Polden; $2530^{b}$ & SMG 273 & Pfennig and Trüper (17) \\
\hline Rhodopseudomonas sphaeroides & ATH 2.4.1. $c$ & ATCC 17023 & van Niel $(25)^{d}$ \\
\hline Rhodospirillum fulvum & KK; Kleinkalden, $1360^{c}$ & ATCC 15798, SMG 113 & Pfennig et al. (18) \\
\hline Thiocystis gelatinosa & Langvik; $2611^{b}$ & SMG 215 & $\begin{array}{l}\text { Pfennig and Trüper } \\
(17, \text { see also } 19)\end{array}$ \\
\hline Thiodictyon bacillosum & Zeulenroda; $1814^{b}$ & SMG 234 & Pfennig and Trüper (17) \\
\hline Thiodictyon elegans .. & Bergkamen; $3011^{c}$ & SMG 232 & Pfennig et al. (19) \\
\hline
\end{tabular}

\footnotetext{
$a$ SMG, Sammlung für Mikroorganismen Göttingen; ATCC, American Type Culture Collection.

$b$ Previous designation of neotype by Pfennig and Trüper (17).

$c$ Strains previously suggested as neotypes, but not in accordance with the rules of the Bacteriological Code; here designated as the neotype strain.

$d$ C. B. van Niel reported (personal communication) that this is one of the strains on which his description of the species was based.
} 
TABLE 3. Additional strains of phototrophic bacteria here designated as neotypes

\begin{tabular}{|c|c|c|c|}
\hline Species & $\begin{array}{c}\text { Author of } \\
\text { species name }\end{array}$ & $\begin{array}{l}\text { Original strain desig- } \\
\text { nation (isolated by) }\end{array}$ & $\begin{array}{l}\text { Culture collection } \\
\text { no. } a\end{array}$ \\
\hline Amoebobacter roseus & Winogradsky $1888(27)$ & Davis; 6611 (Pfennig) & SMG 235 \\
\hline Chlorobium limicola & Nadson 1906 (11) & GHS; 6330 (Pfennig) & SMG 245 \\
\hline Chlorobium vibrioforme & Pelsh $1936(12)$ & Moss Ldg.; 6030 (Pfennig) & SMG 260 \\
\hline Chromatium gracile . . . . . . . . . . . & Strzeszewski 1913 (22) & Hadley Harbor; 8611 (Trüper) & SMG 203 \\
\hline Chromatium minus . . . . . . . . . . . . . & Winogradsky $1888(27)$ & Reyershausen; 1211 (Pfennig) & SMG 178 \\
\hline Chromatium minutissimum . . . . . . . & Winogradsky $1888(27)$ & Glubokoe (Kondratieva) & KMMGU Glubokoe \\
\hline Chromatium okenii . . . . . . . . . . & (Ehrenberg) Perty $1852(13)$ & Ostrau; 1111 (Pfennig) & SMG 169 \\
\hline Chromatium vinosum & (Ehrenberg) Winogradsky $1888(27)$ & D (Roelofsen) & SMG 180; ATCC 17899 \\
\hline Chromatium violascens & Perty $1852(13)$ & Carmel River; 6111 (Pfennig) & SMG 198; ATCC 17096 \\
\hline Chromatium warmingii & (Cohn) Migula $1900(9)$ & Melbourne; 6512 (Pfennig) & SMG 173; ATCC 14959 \\
\hline Chromatium weissei & (Perty) van Niel 1948 (26) & Göttingen; 2111 (Pfennig) & SMG 171 \\
\hline Rhodopseudomonas capsulata & (Molisch) yan Niel 1944 (25) & ATH 2.3.1 (van Niel) & ATCC 11166 \\
\hline Rhodopseudomonas gelatinosa & (Molisch) van Niel 1944 (25) & ATH 2.2.1 (van Niel) & ATCC 17011 \\
\hline Rhodopseudomonas palustris . . & (Molisch) van Niel 1944 (25) & Pal6; ATH 2.1.6 (van Niel) & ATCC 17001 \\
\hline Rhodospirillum photometricum & Molisch 1907 (10) & 132 (Eimhjellen) & NTHC 132 \\
\hline Rhodospirillum rubrum ..... & (Esmarch) Molisch 1907 (10) & S1 (van Niel) & ATCC $11170 ;$ NCIB 8355 \\
\hline Thiocapsa roseopersicina & Winogradsky 1888 (27) & Hardenberg; 1711 (Pfennig) & SMG 217 \\
\hline Thiocystis violacea & Winogradsky 1888 (27) & Grünenplan; 2711 (Pfennig) & SMG 207 \\
\hline Thiospirillum jenense & (Ehrenberg) Migula 1900 (9) & Ostrau; 1112 (Pfennig) & SMG 216 \\
\hline
\end{tabular}

a SMG Sammlung für Mikroorganismen Göttingen; KMMGU, Collection of Microorganisms of Moscow State University, Moscow, USSR; ATCC, American Type Culture Collection; NCIB, National Collection of Industrial Bacteria, Aberdeen, Scotland. 
TABLE 4: Morphological and structural properties of the neotype strains of Chromatiaceae and Chlorobiaceae listed in Table 3

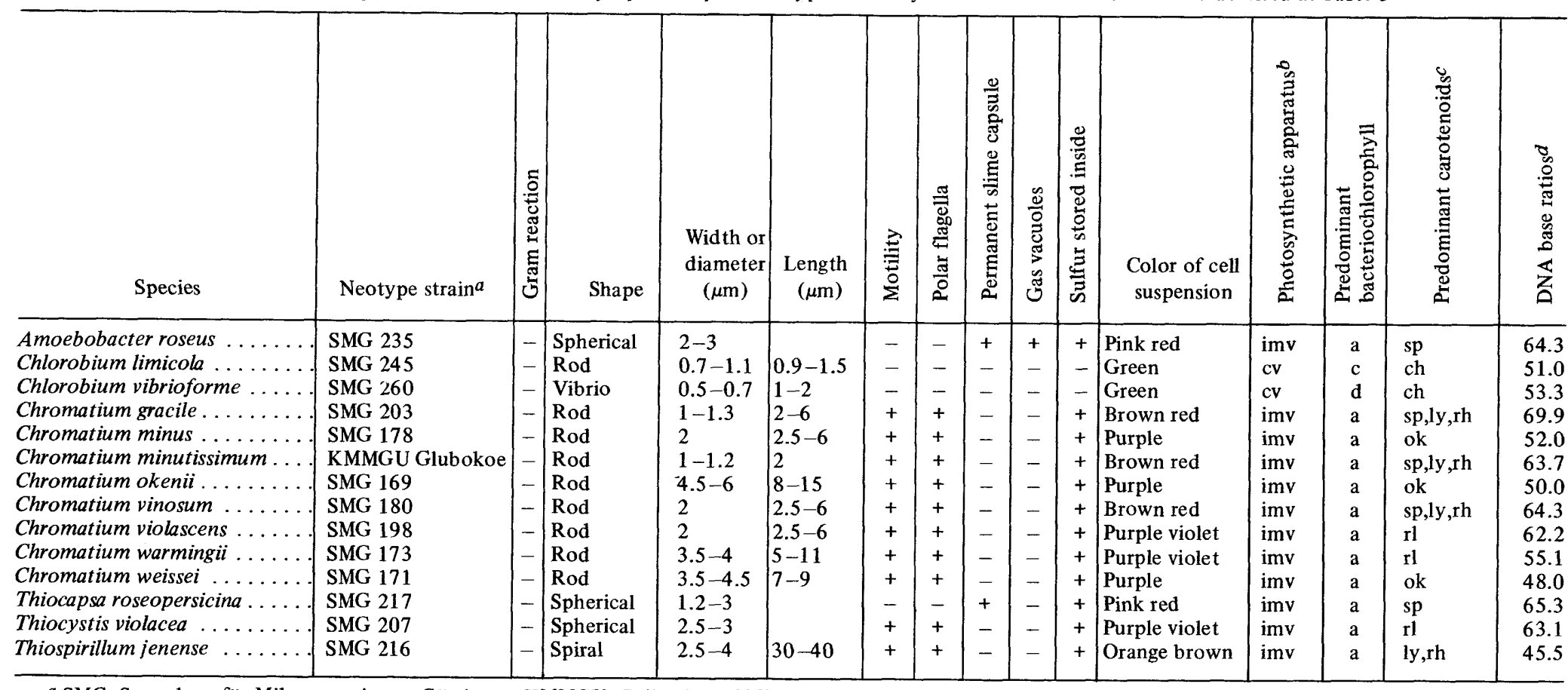

$b$ L , Sammlung für Mikroorganismen Göttingen; KMMGU, Collection of Microor

$c$ sp, Spirilloxanthin; ch, chlorobactene; rh, rhodopin; rl, rhodopinal; ly, lycopene; ok, okenone.

$d$ Moles per cent guanine plus cy tosine. 
TABLE 5: Physiological and biochemical properties of the neotype strains of Chromatiaceae and Chlorobiaceae listed in Table 3

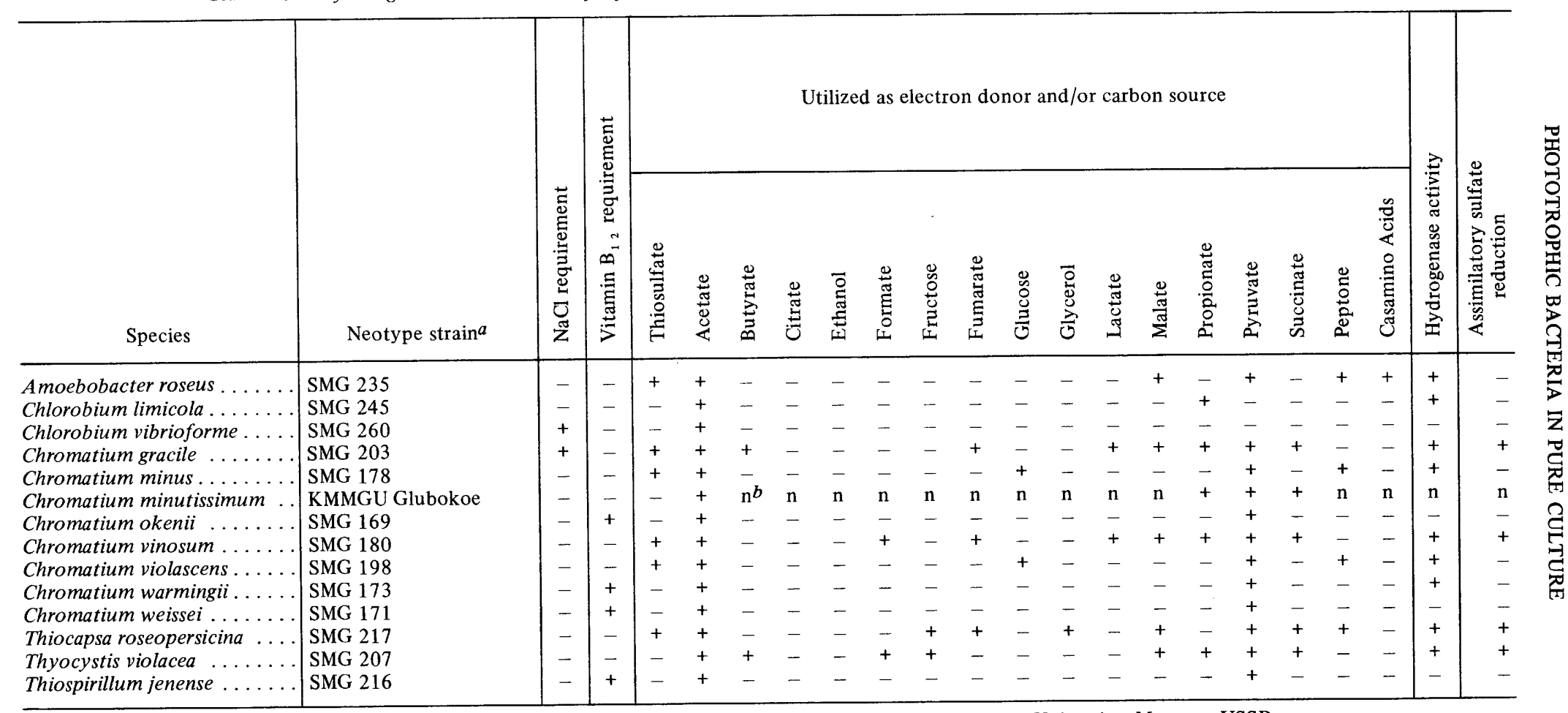

a SMG, Sammlung für Mikroorganismen Göttingen; KMMGU, Collection of Microorganisms of Moscow State University, Moscow, USSR.

$b \mathrm{n}$, Not tested or not available from the literature. 
$10 \mathrm{~mm}$ below the surface (cells are fully pigmented). Capable of growth under strictly anaerobic conditions in the light in media containing citrate, ethanol, fatty acids, fructose, hydroxy acids, or asparagine as substrates.

Not utilized: glucose, glycerol, sulfide, or thiosulfate.

Deoxyribonucleic acid (DNA) base ratio: 65.8 moles per cent guanine plus cytosine (buoyant density).

The differentiating properties of the neotype strains for species belonging to the Chromatiaceae and Chlorobiaceae listed in Table 3 are given in Tables 4 and 5 . Common properties of the strains listed in Tables 4 and 5 are their obligate phototrophy, anaerobic way of life, and ability to utilize sulfide and elemental sulfur as photosynthetic electron donors.

\section{ACKNOWLEDGMENT}

We thank Manley Mandel for the determination of the DNA base ratios.

\section{LITERATURE CITED}

1. Cherni, N. E., J. V. Solovieva, V. D. Fedorov, and E. N. Kondratieva. 1969. Ultrastructure of two species of purple sulfur bacteria. Mikrobiologiya 38:479-484.

2. Drews, G., and P. Giesbrecht. 1966. Die Bezeichnung des Stammes F von Rhodopseudomonas viridis als Typ-Stamm. Arch. Mikrobiol. 55:91-92.

3. Duchow, E., and H. C. Douglas. 1949. Rhodomicrobium vannielii, a new photoheterotrophic bacterium. J. Bacteriol. 58:409-416.

4. Eimhjellen, K. E. 1970. Thiocapsa pfennigii sp. nov., a new species of the phototrophic sulfur bacteria. Arch. Mikrobiol. 73:193-194.

5. Giesberger, G. 1947. Some observations on the culture, physiology and morphology of some brown-red Rhodospirillum species. Leeuwenhoek Ned. Tijdschr. 13:135-148.

6. Gorlenko, V. M. 1970. A new phototrophic green sulphur bacterium-Prosthecochloris aestuaril nov. gen. nov. spec. Z. Allg. Mikrobiol. 10:147-149.

7. International Code of Nomenclature of Bacteria. 1966. Int. J. Syst. Bacteriol. 16:459-490.

8. Lauterborn, R. 1916. Die sapropelische Lebewelt. Verh. Deut. Naturhist. Med. Ver. Heidelberg 13:395-481.

9. Migula, W. 1900. Das System der Bakterien, vol. 2. Gustav Fischer, Jena.

10. Molisch, H. 1907. Die Purpurbakterien nach neuen Untersuchungen. G. Fischer, Jena.

11. Nadson, G. A. 1906. The morphology of inferior algae. III. Chlorobium limicola Nadson, the green chlorophyll bearing microbe. Bull. Jard. Bot. St. Pétreb. (Russian) 6:190.

12. Pelsh, A. D. 1936. Hydrobiology of Karabugaz. Trud. Solyan. Lab. Akad. Nauk USSR, Moscow 5:49-80.

13. Perty, M. 1852. Zur Kenntnis kleinster Lebensformen. Jent and Reinert, Bern.

14. Pfennig, N. 1968. Chlorobium phaeobacteroides nov. spec. und Chlorobium phaeovibrioides nov. spec., zwei neue Arten der grïnen Schwefelbakterien. Arch. Mikrobiol. 63:224-226.

15. Pfennig, N. 1969. Rhodopseudomonas acidophila sp.n., a new species of the budding purple nonsulfur bacteria. J. Bacteriol. 99:597-602.

16. Pfennig, N. 1969. Rhodospirillum tenue sp.n., a new species of the purple nonsulfur bacteria. J. Bacteriol. 99:619-620.

17. Pfennig, N., and H. G. Trüper. 1971. New nomenclatural combinations in the phototrophic sulfur bacteria. Int. J. Syst. Bacteriol. 21:11-14.

18. Pfennig, N., K. E. Eimhjellen, and S. L. Jensen. 1965. A new isolate of the Rhodospirillum fulvum group and its photosynthetic pigments. Arch. Mikrobiol. 51:258-266.

19. Pfennig, N., M. C. Markham, and S. L. Jensen. 1968. Carotenoids of Thiorhodaceae. 8. Isolation and Characterization of a Thiothece, Lamprocystis and Thiodictyon strain and their carotenoid pigments. Arch. Mikrobiol. 62:178-191.

20. Raymond, J. C., and W. R. Sistrom. 1969. Ectothiorhodospira halophila, a new species of the genus Ectothiorhodospira. Arch. Mikrobiol. 69:121-126.

21. Shaposhnikov, V. N., E. N. Kondratieva, and V. D. Fedorov. 1960. A new species of green sulfur bacteria. Nature (London) 187:167-168.

22. Strzeszewski, B. 1913. Zur Kenntnis der Schwefelflora in der Umgebung von Krakau. Bull. Acad. Sci. Cracovie, Ser. B. 1913:309-334.

23. Trüper, H. G. 1968. Ectothiorhodospira mobilis Pelsh, a photosynthetic sulfur bacterium depositing sulfur outside the cells. J. Bacteriol. 95:1910-1920.

24. Trüper, H. G., and H. W. Jannasch. 1968. Chromatium buderi nov. spec., eine neue Art der grossen Thiorhodaceae. Arch. Mikrobiol. 61:363-372.

25. van Niel, C. B. 1944. The culture, general physiology, morphology, and classification of the nonsulfur purple and brown bacteria. Bacteriol. Rev. 8:1-118.

26. van Niel, C. B. 1948. Suborder III. Rhodobacteriineae Breed, Murray and Hitchens, p. 838-860. In R. S. Breed, E. G. D. Murray, and A. P. Hitchens (ed.), Bergey's manual of determinative bacteriology, 6 th ed. The Williams \& Wilkins Co., Baltimore.

27. Winogradsky, S. 1888. Beiträge zur Morphologie und Physiologie der Bacterien. Heft 1. Zur Morphologie und Physiologie der Schwefelbacterien. A. Felix, Leipzig. 